\title{
Hysteresis effects in organic matter turnover in a tropical floodplain during a flood cycle
}

\author{
Alissa Zuijdgeest $\cdot$ Simon Baumgartner $\cdot$ Bernhard Wehrli
}

Received: 21 March 2016/Accepted: 11 October 2016/Published online: 21 October 2016

(C) The Author(s) 2016. This article is published with open access at Springerlink.com

\begin{abstract}
Tropical inland waters are increasingly recognized for their role in the global carbon cycle, but uncertainty about the effects of such systems on the transported organic matter remains. The seasonal interactions between river, floodplain, and vegetation result in highly dynamic systems, which can exhibit markedly different biogeochemical patterns throughout a flood cycle. In this study, we determined rates and governing processes of organic matter turnover. Multi-probes in the Barotse Plains, a pristine floodplain in the Upper Zambezi River (Zambia), provided a high-resolution data set over the course of a hydrological cycle. The concentrations of oxygen, carbon dioxide, dissolved organic carbon, and
\end{abstract}

Responsible Editor: Chris D. Evans

Electronic supplementary material The online version of this article (doi:10.1007/s10533-016-0263-z) contains supplementary material, which is available to authorized users.

A. Zuijdgeest $(\square) \cdot S$. Baumgartner $\cdot$ B. Wehrli Department of Environmental Systems Science, Institute of Biogeochemistry and Pollutant Dynamics, Aquatic Chemistry, ETH Zürich, Universitätstrasse 16- CHN F14, 8092 Zurich, Switzerland e-mail: alissa.zuijdgeest@usys.ethz.ch

A. Zuijdgeest · B. Wehrli

Surface Waters-Research and Management, Eawag,

Swiss Federal Institute of Aquatic Science and

Technology, Seestrasse 79, 6047 Kastanienbaum,

Switzerland suspended particulate matter in the main channel showed clear hysteresis trends with expanding and receding water on the floodplain. Lower oxygen and suspended matter concentrations prevailed at longer travel times of water in the floodplain, while carbon dioxide and dissolved organic carbon concentrations were higher when the water spent more time on the floodplain. Maxima of particulate loads occurred before highest water levels, whereas the maximum in dissolved organic carbon load occurred during the transition of flooding and flood recession. Degradation of terrestrial organic matter occurred mainly on the floodplain at increased floodplain residence times. Our data suggest that floodplains become more intense hotspots at prolonged travel time of the flood pulse over the floodplain.

Keywords Organic matter · Floodplain · Inundation · Hysteresis · Flood pulse - Travel time

\section{Introduction}

In light of increased atmospheric carbon dioxide $\left(\mathrm{CO}_{2}\right)$ concentrations, research is focusing on the role of the different compartments in the global carbon cycle. Inland waters have traditionally been somewhat neglected, being treated as plumbing to transport terrestrial carbon to the oceans (Melack 2011). Streams, rivers, artificial and natural lakes, wetlands, 
and floodplains, which cover approximately 4.6 million $\mathrm{km}^{2}$ or $>3 \%$ of the terrestrial realm (Downing et al. 2006), have been identified as important biogeochemical reactors within the global cycle (Raymond et al. 2013). Recent work has emphasized that inland waters remove carbon via burial (Battin et al. 2009) and emissions to the atmosphere (Raymond et al. 2013). Global budgets are still lacking important contributions from tropical inland waters, specifically in Africa.

In Africa, heavy seasonal rainfall, associated with monsoons or the Intertropical Convergence Zone, inundates large floodplain areas along most tropical rivers. Such floodplains are characterized by distinct hydrology, soil conditions, and vegetation, and they support significantly different ecosystems at the border of terrestrial and aquatic zones (Mitsch and Gosselink 2007). After the onset of the rains, discharge increases, and water from the main channel (henceforth referred to as river water) is forced onto the floodplain, causing a flooding event (Ward and Stanford 1995). The interaction between the flood pulse and the floodplain creates transition zones between terrestrial and aquatic habitats (Junk et al. 1989). The return of floodplain water into the main channel delivers organic matter, particles, and nutrients that were released from the floodplain soils into the water on the floodplain, which can sustain high aquatic productivity in the river-floodplain system (Robertson et al. 1999; Ward and Stanford 1995).

The temporal variability in inundation and hence aquatic and terrestrial habitats leads to distinct vegetation patterns on floodplains, first summarized in the Flood Pulse Concept (Junk et al. 1989). Whereas the rapid water flow in the main channel is typically unfavorable for intense primary production, aquatic macrophytes and periphyton in the riparian zone and on the floodplain usually contribute to high primary production rates. In slow-flowing tropical rivers, floating macrophytes could have greater importance (Junk et al. 1989). Rivers and streams are on a global scale net heterotrophic, even without considering bordering floodplains and wetlands (Battin et al. 2008). On various floodplains the initial flood pulse resulted in high respiration rates (Chaparro et al. 2014; Gallardo et al. 2012; Marcarelli et al. 2010), while production of biomass accumulated during dryer periods (Gallardo et al. 2012). The seasonal flooding results in highly dynamic, temporally and spatially variant interactions between the riparian terrestrial ecosystems and the river.

Floodplains in the Okavango delta are considered sources of dissolved organic carbon (DOC), particularly during the annual flood (Mladenov et al. 2005). Leaching of DOC from vegetation, particularly leaf litter, occurs rapidly after the vegetation is first wetted (O'Connell et al. 2000). Based on studies in five different river-floodplain systems in the U.S.A, Peru, and Venezuela, inputs of terrestrial organic matter were more important to the aquatic food webs during high flow (Roach et al. 2014). In contrast, in the Amazon organic matter was exported from the river onto the floodplain during rising water levels, whereas organic matter produced by phytoplankton and macrophytes on the floodplain was transferred back to the river during high and falling water levels (MoreiraTurcq et al. 2013). Interactions between a flood pulse and the river's floodplains have been shown to alter the dissolved organic carbon concentrations and sources throughout the year.

River-floodplain exchange has also been found to affect the in-stream oxygen concentrations. Inputs of oxygen-depleted floodplain water significantly lowered the oxygen concentrations at the downstream end of a large floodplain in Zambia (Zurbrügg et al. 2012). Similarly, low oxygen concentrations were found on the floodplains in the Paraguay River Basin (Hamilton et al. 1995). The Atchafalaya River, a tributary of the Mississippi, experiences low dissolved oxygen concentrations along one of its floodplain areas during receding water levels (Kaller et al. 2015). Higher respiration rates in floodplain areas and decreasing oxygen concentrations in the downstream direction were also found in the Macquarie River in Australia (Kobayashi et al. 2011). In general, higher respiration rates on the floodplain are responsible for low oxygen conditions in the floodplain water, which in turn affects the oxygen concentration in the river water at downstream locations.

Floodplain systems are also hotspots in terms of greenhouse gas emissions (Raymond et al. 2013). In the Amazon catchment, floodplain areas were found to be emitting larger quantities of $\mathrm{CO}_{2}$ to the atmosphere than previously considered for tropical systems (Richey et al. 2002). Similar to the flooded forests of the Central Amazon Basin, inter-fluvial wetlands in the Negro River catchment emitted $\mathrm{CO}_{2}$ to the atmosphere (Belger et al. 2011), showing that high 
evasive fluxes can be expected from any type of flooded ecosystem. In a tropical wetland in Australia, emissions of $\mathrm{CO}_{2}$ varied among different habitats (Bass et al. 2014). The high emission rates in the Amazon catchment led to revised global budgets (Raymond et al. 2013).

The importance of river-floodplain interactions for different components of the river biogeochemistry has been highlighted and studied, but an integrative view of the effects in tropical floodplains is still lacking. Due to the high anthropogenic burden on many tropical systems, it is imperative to gain a mechanistic understanding of the biogeochemical cycling in remaining pristine systems, before these disappear altogether.

To gain such a holistic overview of river-floodplain interactions, we continuously observed water quality parameters up- and downstream of the Barotse Plains in the upper Zambezi basin, a large, pristine floodplain at high temporal resolution over a flooding cycle with deployed multi-probes. This procedure allows estimating the biogeochemical transformations occurring in the floodplain system as a function of time. The temporal resolution of our data set allows characterization of seasonal patterns, instead of capturing only snapshots in time. We aim to (1) determine the seasonal patterns of organic matter cycling during a hydrological cycle, (2) understand which processes are responsible for these patterns, and (3) evaluate on which time scales these processes affect the river biogeochemistry.

\section{Methods}

Study site

The Zambezi River Basin is the fourth largest in Africa at $1.4 \times 10^{6} \mathrm{~km}^{2}$, and the only one of the major African rivers draining into the Indian Ocean. Due to its location in the Southern Hemisphere, the catchment experiences a pronounced wet season during the passage of the Inter Tropical Convergence zone from December to March followed by a dry season from April to November. The Barotse Plains are a nearpristine floodplain area with low population density of roughly 6 people per $\mathrm{km}^{2}$ (Euroconsult Mott MacDonald 2007) in the upstream part of the Zambezi River in Western Zambia (Fig. 1). The main body of the floodplain area is estimated around $7700 \mathrm{~km}^{2}$ (Hughes and Hughes 1992). The hydrograph in the Barotse Plains shows peak flow in April-May and low-flow conditions between July and November.

Previous research in the Zambezi basin has shown that the catchment exports large quantities of DOC at very high flow (Lambert et al. 2016; Zurbrügg et al. 2013), and that the organic matter cycling is strongly impacted by the presence of hydropower dams in the catchment (Kunz et al. 2011a, b; Wamulume et al. 2011; Zurbrügg et al. 2013). Emissions of greenhouse gases have been linked to natural barriers (waterfalls), and hydropower reservoirs (DelSontro et al. 2011), and the presence of floodplain areas, with highest concentrations of $\mathrm{CO}_{2}$ and methane found just downstream of extensive floodplain areas (Teodoru et al. 2015). Temporal variations of concentrations and trends in dissolved and particulate organic carbon (DOC and POC, respectively) and greenhouse gases in the river system have been observed between periods of high and low flows (Teodoru et al. 2015; Zuijdgeest et al. 2015; Zurbrügg et al. 2013).

Probe deployment

At two locations in the Zambezi River Basin (Fig. 1) we have deployed WTW EXO2 probes, at the upstream end of the Barotse Plains, just south of Lukulu $\left(14.5340^{\circ} \mathrm{S}, 23.1466^{\circ} \mathrm{E}\right)$ and at the downstream end in Senanga $\left(16.0994^{\circ} \mathrm{S}, 23.2963^{\circ} \mathrm{E}\right)$. At Lukulu, the probe was deployed in the middle of one of two branches of the river, which both carry water year-round. Previous research (not published) showed there was little variation in biogeochemical composition of the water in the two branches. The probe in Senanga was deployed from a floating jetty, roughly $5 \mathrm{~m}$ from an outer bend of the river. The Zambezi was horizontally well-mixed (Zuijdgeest et al. 2015). Though there typically is some flooding upstream of the first sensor location, the bulk of the seasonal flooding occurs between these two locations. At both locations, daily water level measurements are available from the Zambezi River Authority. At Senanga the water level data can easily be correlated to discharge measurements at Ngonye Falls, somewhat further downstream of the floodplain.

At hourly intervals, the instruments logged for $60 \mathrm{~s}$ temperature, conductivity, $\mathrm{pH}$, dissolved oxygen, fluorescent dissolved organic matter (fDOM), and 


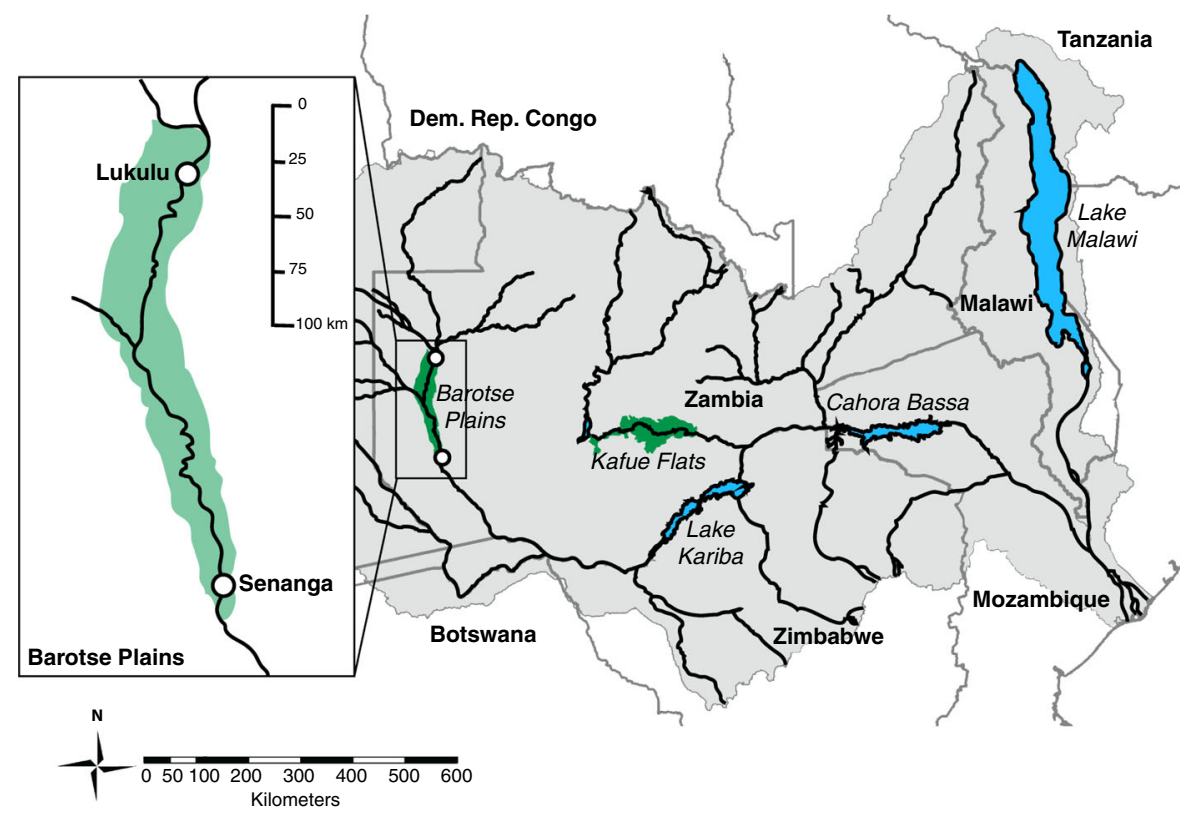

Fig. 1 Map of the Zambezi catchment, with the extension of the Barotse floodplain and the locations of the sensors shown in the inset

turbidity. Automated wiping of the sensors with a small brush prior to measurement ensured high-quality data from the sensors. Both probes were deployed in early November 2013, serviced in April 2014 and the measurement interval was set to $9 \mathrm{~h}$ for the remainder of the deployment, and retrieved in September 2014. Service included new batteries and recalibration of the sensors, though the observed drifting was minimal. Unfortunately, both probes have experienced interrupted data collection: in Lukulu the measurements after service were not recorded properly, and in Senanga the period between March 11 and service (April 12) is missing due to a short-circuit in the temperature/conductivity sensor.

At the times of deployment, service, and retrieval, additional water samples were collected before stopping the deployment. Samples for alkalinity were stored cold and determined in the laboratory by endpoint titration. Filtered water $(\mathrm{GF} / \mathrm{F}, 0.7 \mu \mathrm{m}$; Whatman) was collected in $12 \mathrm{~mL}$ Exetainer vials and poisoned with $\mathrm{CuCl}_{2}$ for analysis of dissolved inorganic carbon (DIC) and in $40 \mathrm{~mL}$ glass vials and acidified with $100 \mu \mathrm{L} 2 \mathrm{M} \mathrm{HCl}$ for analysis of dissolved organic carbon. Both were analyzed in the laboratory on a Shimadzu TOC-L Analyzer. Suspended particulate matter (SPM) concentrations were determined by weight difference on $\mathrm{GF} / \mathrm{F}$ filters $(0.7 \mu \mathrm{m}$; Whatman) after freeze-drying for at least
24 h. During various other sampling campaigns in the Zambezi catchment (October 2013, June 2015), the same kind of samples have been collected simultaneous with discrete measurements with an EXO2 probe.

Calibrations and calculations for organic matter and the carbonate system

During the field campaigns and servicing trips related to the deployment, simultaneous measurements with the $\mathrm{EXO} 2$ probe and water samples for laboratory analysis were collected. From this data set, we determined correlations between fluorescent dissolved organic matter and DOC (Fig. 2a), and between turbidity and SPM (Fig. 2b). High-turbidity values ( $>20$ FNU) were filtered out of the data set because of uncertainty about measurement accuracy. We used the conductivity record to calculate the alkalinity changes over time (Fig. 2c). Correlations between conductivity and alkalinity result from natural geological and climatic controls and are often used to assess anthropogenic impacts on streams or rivers (Kney and Brandes 2007; Stewart 2001; Thompson et al. 2012). Preliminary data from the upstream catchment of the Zambezi (upstream of Lake Kariba) indicated a strong correlation between conductivity and alkalinity during high water levels (April 2013). The initial data has been expanded with additional measurements at the 

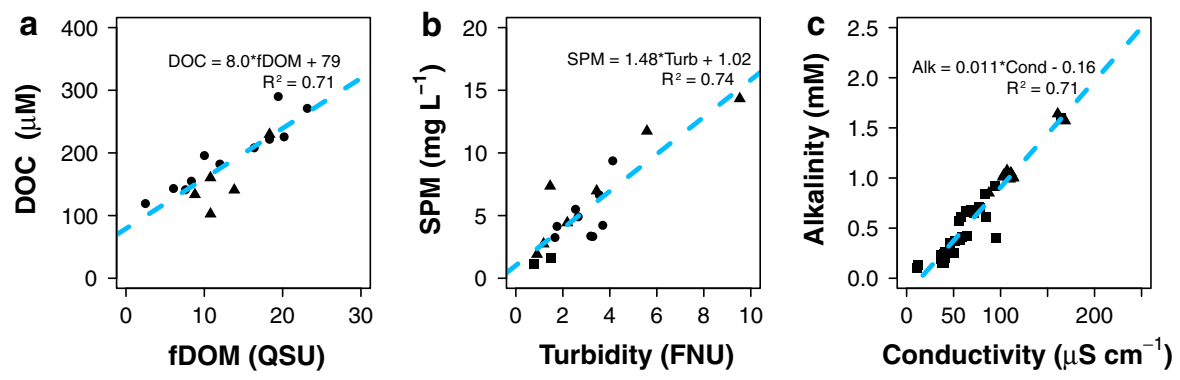

Wet season

Dry season Receding water

Fig. 2 Correlations based on samples from November 2013, April 2014, and June 2015 between a fluorescent dissolved organic matter $(\mathrm{fDOM})$ and DOC $(r=0.722, \mathrm{p}=7.16 \mathrm{e}-4)$,

sampling locations, and measurements by Teodoru et al. (2015), confirming a clear correlation between conductivity and alkalinity (Fig. 2c; more details in Online Resource 2). By combining the conductivitybased alkalinity data with measured $\mathrm{pH}$, temperature, and salinity, the entire carbonate system was calculated with the CO2SYS Excel sheet (Pierrot et al. 2006), using the dissociation constants compiled by Millero (1979).

\section{Calculating process rates from sensor data}

Using the hourly oxygen recordings, we applied the diel oxygen method as outlined by Staehr et al. (2010) to calculate gross primary production (GPP), net primary production (NPP), and respiration rates in the river. The underlying assumption in this method is that the change in oxygen concentration over a daily cycled is mainly governed by GPP, respiration, and the diffusive flux. The diffusive flux was calculated using the temperature-dependent oxygen saturation concentration and wind speed data from a nearby meteorological station. During the night no GPP occurs, so from the change in oxygen concentration observed during those hours the respiration rate could be determined, correcting for the diffusive $\mathrm{O}_{2}$ flux. This respiration rate was assumed to be constant throughout the day as well, allowing the calculation of the contribution of primary production to the change in oxygen concentrations over time during daylight hours. These calculations were not possible for the second half of our deployment, because the longer $(9 \mathrm{~h})$ time intervals between measurements did not guarantee two measurements during both day and night. b turbidity and SPM $(r=0.869, p=2.92 \mathrm{e}-6)$, and $\mathbf{c}$ conductivity and alkalinity $(\mathrm{r}=0.966, \mathrm{p}<2.2 \mathrm{e}-16)$

Inundation dynamics

Visual consideration of the two water level records (Fig. 3a) suggested that the downstream record was a time-shifted version of the upstream record. However, because the shift was not constant, a more sophisticated method was needed to calculate the residence time of water in the floodplain area. For this purpose, the dynamic time warping package "dtw" in $\mathrm{R}$ (Giorgino 2009) was used. This procedure stretches and compresses two time series to maximize the correlation between the two (Giorgino 2009). The water level time series at Lukulu was set as the query, to be compressed and stretched to represent the time series at Senanga, the reference. Water level records were first normalized to the mean water level for each record, for ease of calculation and comparison. Calculation was performed using different step patterns, but the mori 2006 pattern (Mori et al. 2006) yielded results that matched visual observations best (see Online Resource 3), and the results from this procedure were used in this study.

Visual comparison of the water level records and the dynamic time warping procedure did not correspond well in the first months of the time series, with negative travel times being calculated. This was probably due to calculation artifacts relating to the boundaries of the time series and small variations in the two records. The travel time at the end of the dry season was therefore manually adjusted to a smooth increase from 3 to 8 days, where the minimum of 3 days is determined based on acoustic Doppler current profiler flow measurements at several locations along the Barotse Plains from April 2013 (Zuijdgeest et al. 2015). At the end of the year, travel times were 

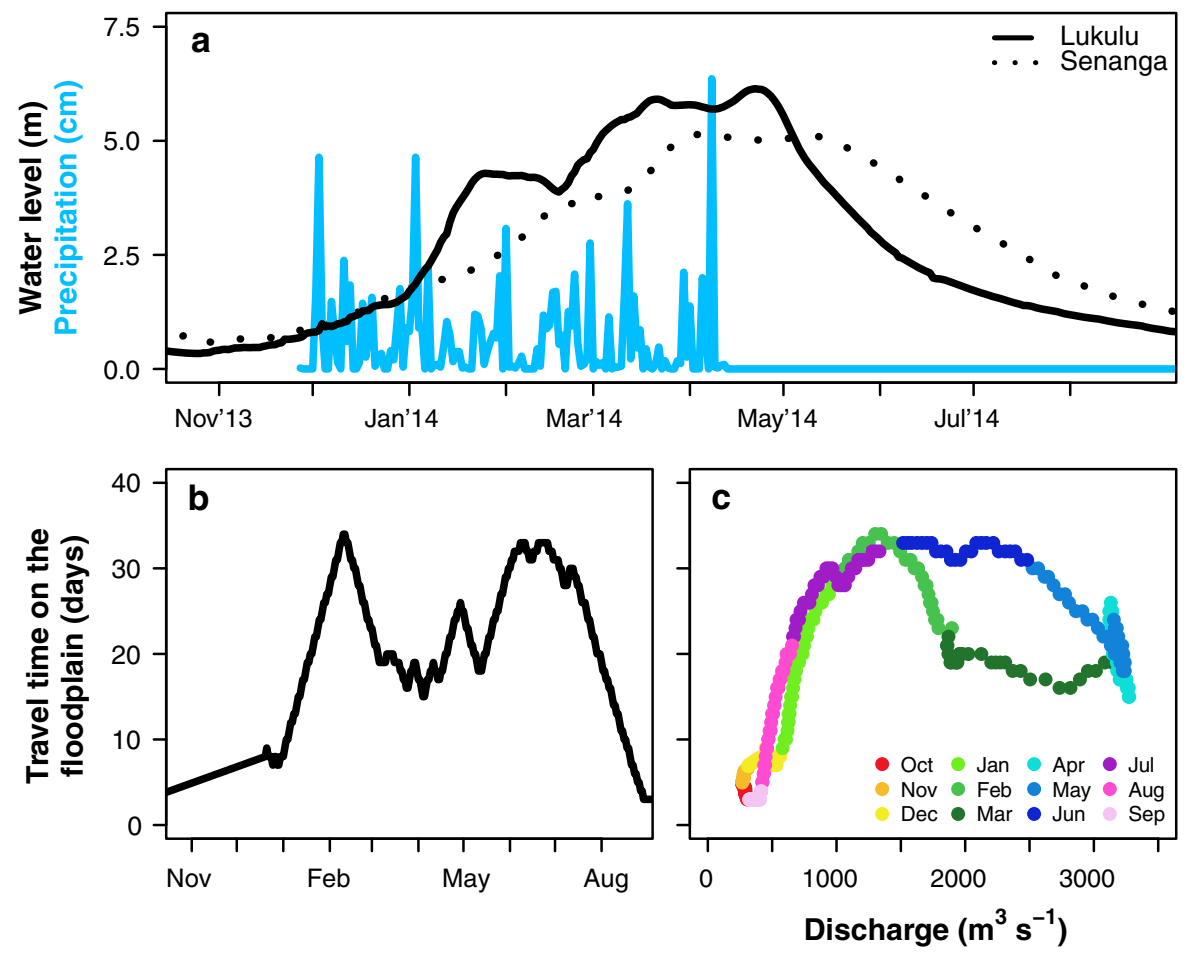

Fig. 3 a Temporal changes in water levels at Lukulu and Senanga and precipitation at Kalabo (in the middle of the floodplain; data from www.biota-africa.org). b Temporal changes in travel time of the flood pulse over the floodplain. The

again set manually to 3 days to match the observations and correct for boundary-related calculation artifacts (Online Resource 3). Unfortunately, it was not possible to obtain water level records for a longer time period, to minimize the boundary effects for the time period of the study. While the algorithm produced robust results over the time of the flood peak and its recession, its accuracy seems to be limited at the boundaries of the time-series. Future methodological tests on multi-year time series could help to clarify and constrain this limitation.

\section{Results}

Hydrology and inundation dynamics

Shortly after the onset of the rains, travel time over the floodplain increased markedly (Fig. 3b). Towards the end of the rainy season prolonged travel times were following larger rain events. Travel times remained first peak in travel time is replaced by a gradual increase based on visual observations, minimum travel times are set to 3 days based on ADCP data from April 2013. c Relationship between travel time and discharge at Senanga

high during receding water (May-July) and only started to decline rapidly at the end of July.

Plotting travel time of the flood pulse over the wetlands against discharge at Senanga revealed a counter-clockwise hysteresis effect (Fig. 3c). The travel time of water between Lukulu and Senanga increased with rising water levels, reaching maximum travel times of approximately 35 days at roughly 1300 $\mathrm{m}^{3} \mathrm{~s}^{-1}$, well before peak flow. During the remaining wet season, travel time decreased again to a steady 20 days until peak flow was reached. Contrastingly, during receding water levels travel time rose again and remained at a maximum of roughly 30 days until discharge dropped below $1000 \mathrm{~m}^{3} \mathrm{~s}^{-1}$. At high discharge, the travel time was distinctly shorter during rising water levels than during receding water levels.

Seasonal patterns of organic matter parameters

The records from Lukulu and Senanga showed distinct temporal shifts in carbon dynamics: while oxygen 
concentrations decreased earlier in the year in Senanga, peak concentrations in $\mathrm{CO}_{2}$ and DOC were observed roughly 1.5 month earlier in Lukulu compared to Senanga. $\mathrm{CO}_{2}$ concentrations almost doubled between the upstream and downstream locations. From mid-May to early-July, the $\mathrm{CO}_{2}$ concentrations in Senanga increased again to a smaller, second peak, as conductivity (i.e. alkalinity; Online Resource 4) rose while $\mathrm{pH}$ remained stable. Suspended matter concentrations in Senanga were high at the end of the dry season and the first months of the wet season, but decreased with increasing discharge (Fig. 4d). Towards the end of our time series a small increase in SPM concentrations was observed. In Lukulu the SPM concentrations were lower than in Senanga throughout the year, and with a less distinct pattern: small maxima were observed mid-December, early January, and early March without any clear seasonal pattern.
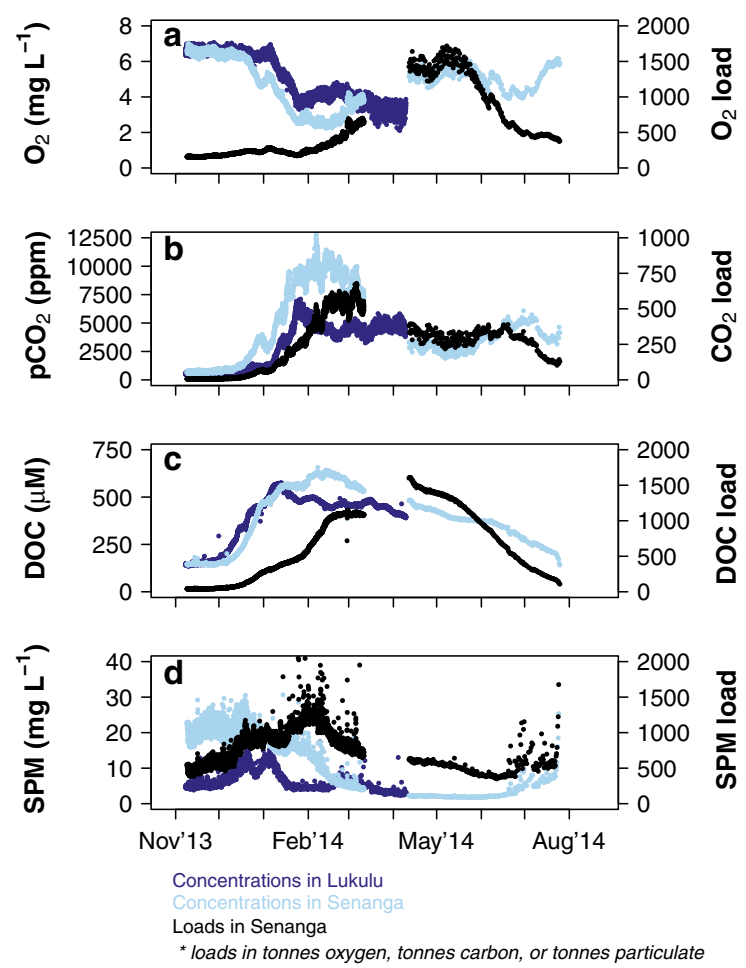

Fig. 4 Temporal changes in oxygen, carbon dioxide, dissolved organic carbon, and suspended particulate matter concentrations and loads throughout the year. Data for Lukulu lacking after servicing in April, recording gap in Senanga between March 11 and April 12
The load of suspended particulate matter peaked earliest in the year, around February, followed by maximum $\mathrm{CO}_{2}$ loads in early March (Fig. 4). Oxygen and DOC peaked somewhat later, around May and early April, respectively.

Hydrology and river biogeochemistry

The observed delay between peaks in $\mathrm{CO}_{2}$ and DOC at Lukulu and Senanga (Fig. 4) clearly showed that processes on the floodplain impacted the biogeochemistry of the downstream location. Correlations with discharge showed hysteresis patterns, with distinctly different regimes during rising and falling water levels: $\mathrm{O}_{2}$ exhibited anti-clockwise hysteresis (Fig. 5a), whereas clockwise hysteresis was observed for $\mathrm{CO} 2$ (Fig. 5b) and DOC (Fig. 5c). Remarkably, SPM concentrations did not show a clear hysteresis pattern: in general, concentrations decreased with increasing discharge, and increased along the same trend when water levels decreased again (Fig. 5d).

The concentration of oxygen showed a distinct anticlockwise hysteresis versus travel time (Fig. 6a), in contrast to the clockwise hysteresis observed in $\mathrm{CO}_{2}$ (Fig. 6b) and DOC concentrations (not shown). DOC concentrations exhibited a pattern similar to $\mathrm{CO}_{2}$, though with more variable concentrations at short travel time (Fig. 6c). SPM, on the other hand, showed high concentrations at short travel times, and lower concentrations when the water spent more time on the floodplain (Fig. 6d). During receding waters, SPM concentrations were generally lower than during rising water levels.

In-stream primary production and respiration

Calculated net primary production in the water column in Senanga (Fig. 7a) decreased from the onset of the deployment, with minimum values towards the end of December. Once productivity reached this minimum, oxygen concentrations started declining. During the remainder of the rainy season, NPP varied without any clear relationship with oxygen concentrations. Respiration rates increased between November and midJanuary, and peaked around the time that oxygen concentrations started to drop (Fig. 7b). During the second half of the rainy season, respiration rates declined again, with oxygen concentrations rising 
Fig. 5 Relationships between oxygen, carbon dioxide, dissolved organic carbon, and suspended matter concentrations in Senanga and discharge. Note the recording gap in Senanga between March 11 and April 12, which resulted in the two disjointed lines

Fig. 6 Relationships between oxygen, carbon dioxide, dissolved organic carbon, and suspended matter concentrations in Senanga and travel time of the flood pulse over the floodplain. Note the recording gap in Senanga between March 11 and April 12 , which resulted in the two disjointed lines
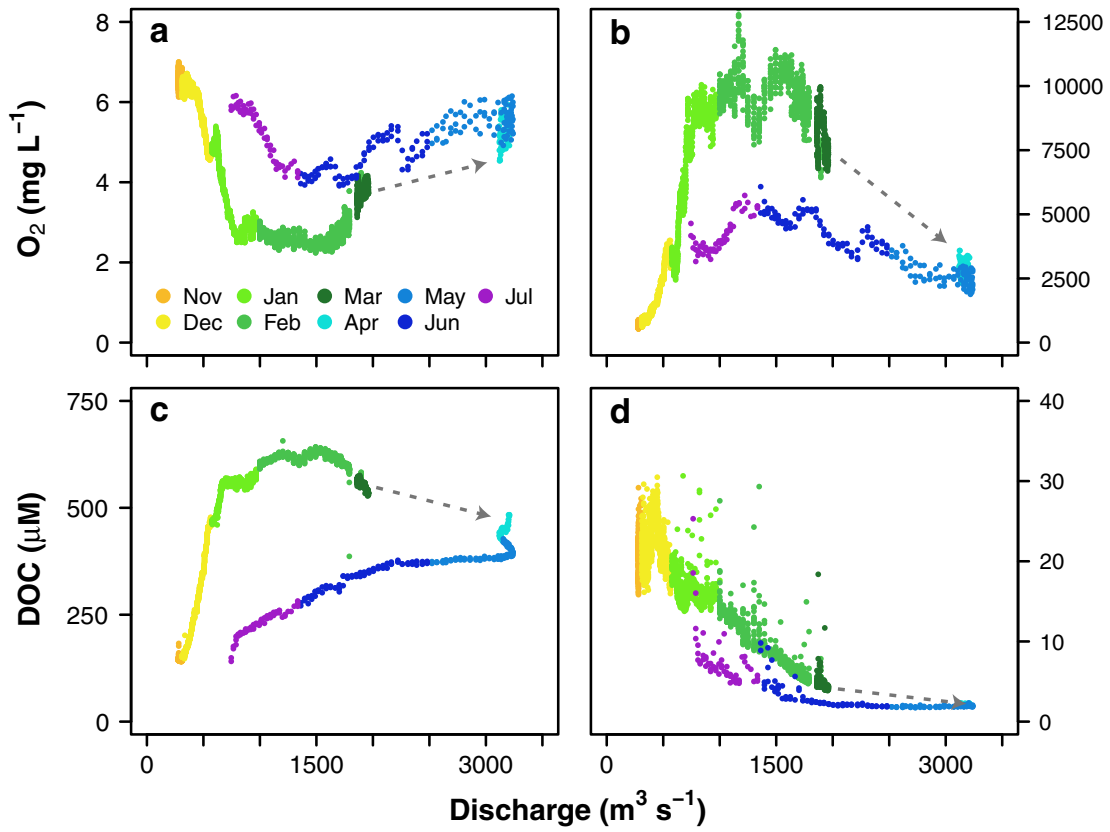

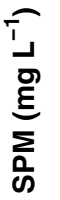
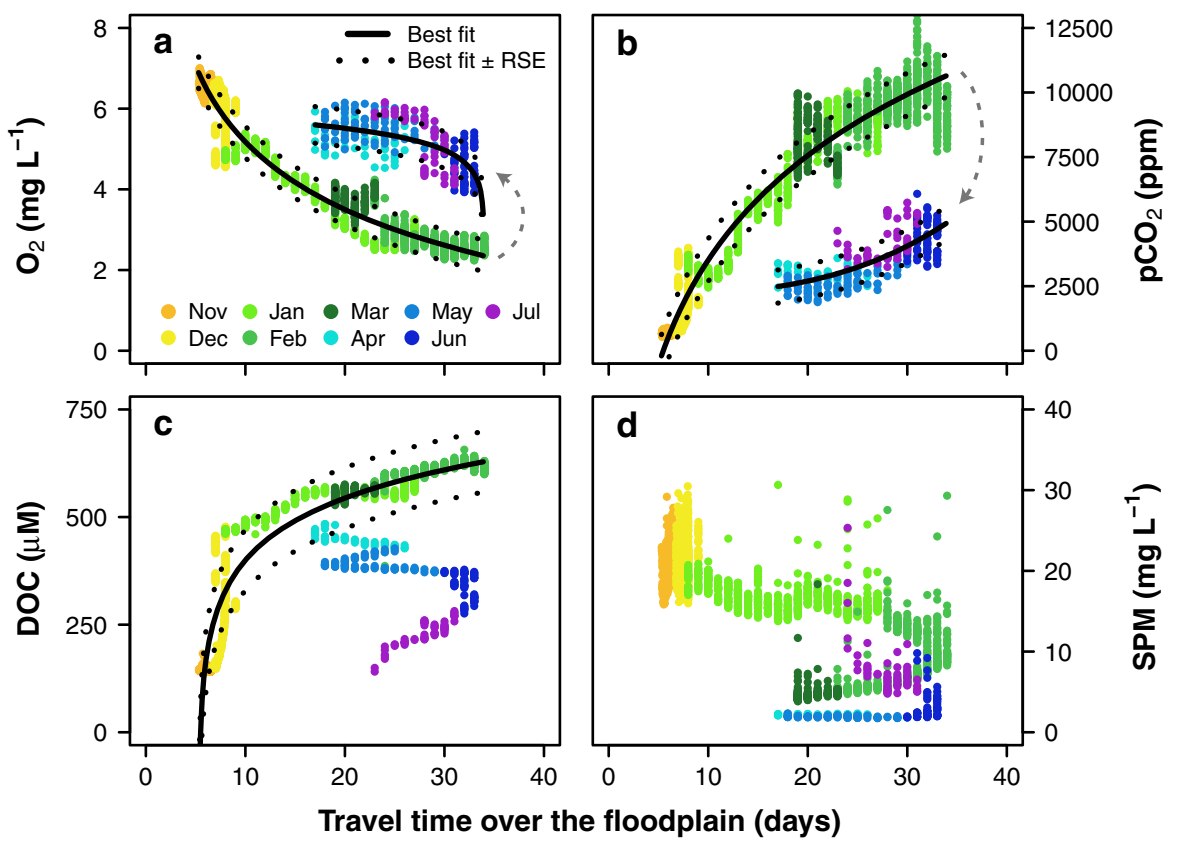



when respiration rates fell. Though we were only able to calculate NPP and respiration rates during the first half of our deployment, that period did see the largest variability in oxygen concentrations in the river water. There was no correlation between river oxygen concentrations and either NPP or respiration (correlation coefficient $r=0.155$ and 0.165 , respectively).

\section{Discussion}

In order to further explore the connections between hydrology and biogeochemistry in the Barotse Plains, we suggest three phases of the seasonal flooding cycle, during which different processes dominate organic matter cycling. This concept can be used to guide 


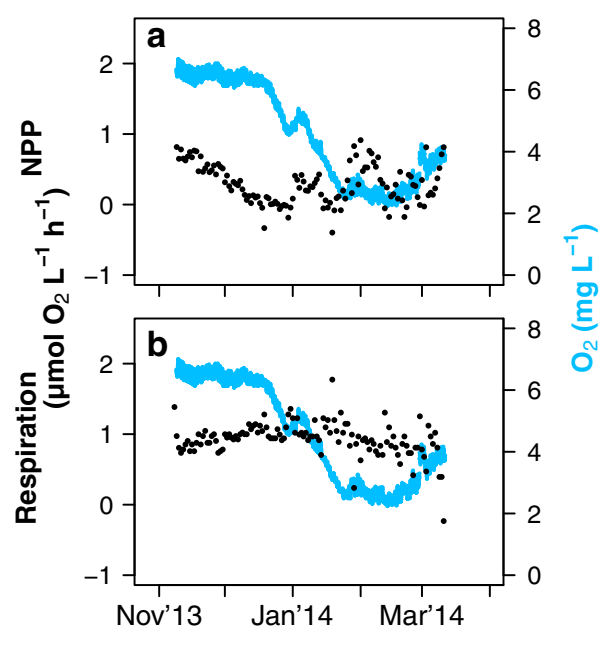

Fig. 7 Oxygen concentrations and a NPP and b respiration rates at Senanga between November 2014 and April 2014. No rates were calculated for the remainder of the year due to longer intervals between measurements

future field research on organic matter cycling and particle mobilization. The travel time of water over the floodplain will be identified as a useful parameter to define model equations for water quality in spatially explicit hydrological models. The travel-time concept offers the potential to generalize the dynamics of floodplain processes across different systems.

Phase 1: expansion

During the initial phases of the flooding season, increasing loads of $\mathrm{CO}_{2}$ and DOC, and decreasing oxygen concentrations in the river were observed. The peak SPM load preceded the maximum of the $\mathrm{CO}_{2}$ load, indicating that the physical soil erosion was triggered by river flow over previously dry soils, whereas the onset of mineralization processes and the subsequent diffusive transport of $\mathrm{CO}_{2}$ from the soil pore space into the flood water required more time. Alternatively, degradation of mineral-bound organic matter could occur in the water column. We hypothesize that the first phase, one of initial flooding, was characterized by intense floodplain soil mobilization, as a consequence of the unprotected floodplain soils at the end of the dry season. Erosion resulted in peak suspended matter loads around February. During the dry season, vegetation on the floodplain shrivels due to lack of water, and typically the biomass is burned before the onset of the rains, to foster new vegetation growth (Andreae 1991; Mitsch et al. 2010). This agricultural practice leaves the floodplain vulnerable to soil mobilization during the first flood pulse. The peak SPM load preceding peak flow has previously been attributed to exhaustion of the sediment source in other highly seasonal systems (Oeurng et al. 2011; Rovira and Batalla 2006). Continued flooding of the Barotse Plains exhausted the initial source of suspended matter, and as flooding spread, progressively smaller amounts of loose floodplain soil were available for mobilization.

Phase 2: maximum

As the wet season progressed, the whole floodplain was inundated and the discharge reached its maximum. With diminishing inflows, the travel time of water over the floodplain increased again to its maximum value (Fig. 8). As a consequence of the maximum travel times, in-stream oxygen concentrations reached minimum values and increasing DOC concentrations were observed. Around March, carbon dioxide and SPM concentrations and loads decreased, whereas oxygen concentrations rose. It is important to notice that the particles behaved differently from the solutes. We suggest that during this second phase, the controlling regime shifted from flooding to stabilization of the floodplain soils. Continued stabilization of the floodplain soils by wetland vegetation also shifted the dominant regime on the floodplain from respiration to primary production, resulting in the uptake of $\mathrm{CO}_{2}$, production of DOC and $\mathrm{O}_{2}$, and minimization of the source of SPM. This would have led to the maximum oxygen loads observed around peak flow, simultaneously with DOC.

The characteristic features of the second phase correspond well to trends recorded for other tropical systems. Strong increases in $\mathrm{pCO}_{2}$ downstream of the Barotse Plains and other flooded systems in the Zambezi catchment have also been observed during the rainy season (Teodoru et al. 2015). The Barotse Plains showed high DOC and low SPM concentrations during peak flow in 2013 (Zuijdgeest et al. 2015). Retention of particulate organic matter and net export of dissolved organic matter indicated degradation processes dominated over primary production in April 2013 (Zuijdgeest et al. 2015). DOC concentrations in the Okavango delta peaked two to four weeks before peak flood (Mladenov et al. 2005). The source of the 


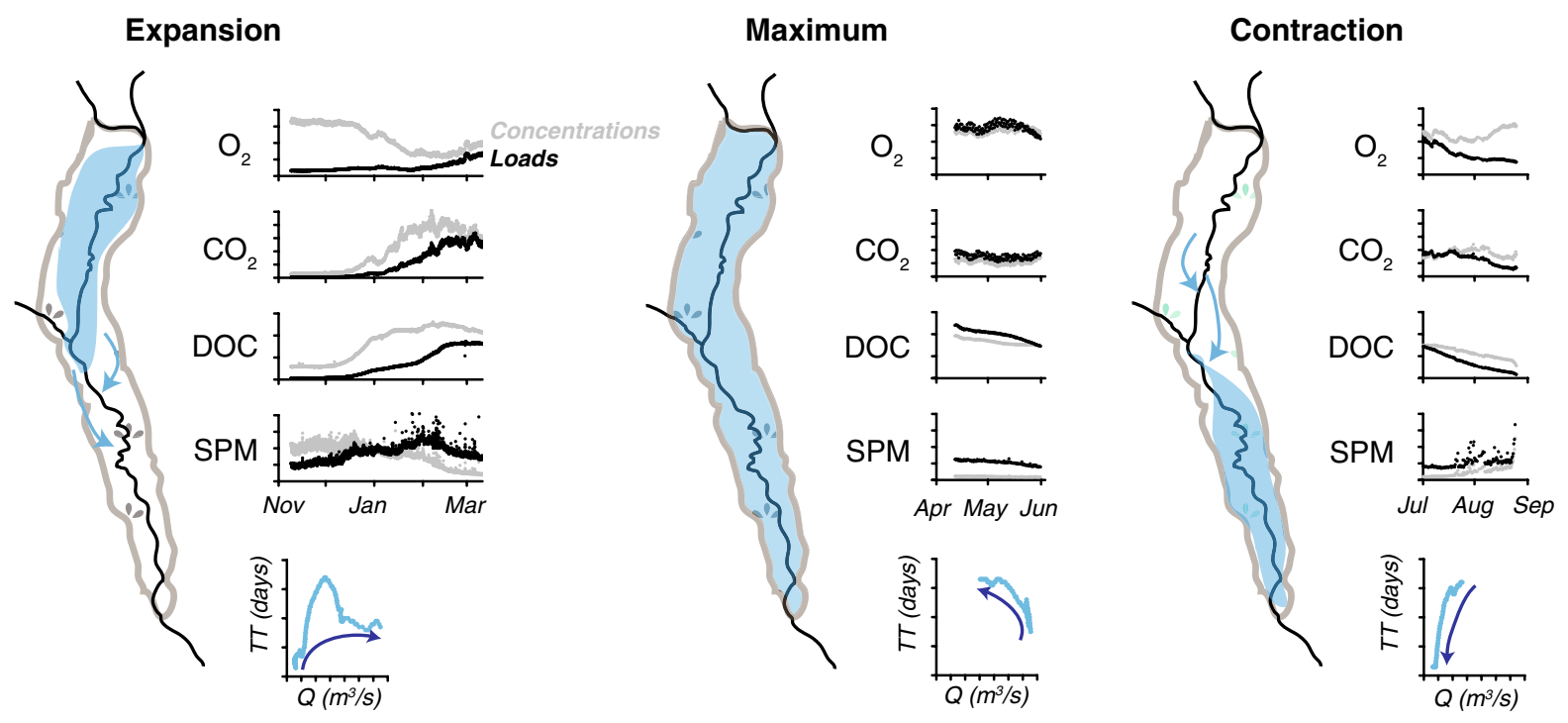

Fig. 8 Conceptual summary of the three phases, with the seasonal concentrations and loads of oxygen, carbon dioxide, dissolved organic carbon, and suspended particulate matter and the relationship between discharge (Q) and travel time (TT)

DOC changed from vascular plant inputs during rising water levels to DOC from the microbial degradation of dissolved organic matter derived from vascular plants during receding water levels (Mladenov et al. 2005). During high and falling water levels, input of organic matter that was produced on the floodplain has been observed in the Amazon (Moreira-Turcq et al. 2013).

Phase 3: contraction

During declining water levels, $\mathrm{CO}_{2}$ levels remained elevated compared to the minimum observed at the end of the dry season and the water column remained well oxygenated. Dissolved organic matter concentrations and loads decreased significantly, but SPM started to rise again sporadically towards the end of the dry season. The observed decrease in $\mathrm{O}_{2}$ concentration and rise in $\mathrm{CO}_{2}$ around July was less extensive than during phase 1 .

During the third phase, we propose that the floodplain sediment source (i.e. bare soil) was mostly depleted, but there was a continuous input of organic matter from the floodplain vegetation to the river, as connectivity between the river and its floodplain remained. Vegetation debris contributed to the suspended pool, and degradation of this source of organic matter kept $\mathrm{CO}_{2}$ levels elevated. The more extensive oxygen consumption at the onset of flooding could be the result washing out of accumulated degradation products soil-associated organic matter, or simply the effect of a larger pool of organic matter to start with. As the lateral connectivity between the floodplain and the river decreases, conditions change towards a rather well confined flow channel typical for the dry season. During this period of only channelized flow, which was not fully captured by our data, we suggest that SPM input came from atmospheric inputs or biomass burning at the end of the dry season.

Travel time as determining factor for riverine biogeochemistry

Travel time of the river water from Lukulu to Senanga was used here as a quantitative indicator for analyzing the biogeochemical effects of water retention on the floodplain. Discharge measurements showed that water flowing through the main channel would reach the downstream end of the floodplain in roughly 3 days during peak flow (April 2013; Zuijdgeest et al. (2015)) and in approximately 6 days during receding water levels (June 2015; unpublished data). However, the offset between water level records at Lukulu and Senanga indicated that the flood pulse took three to four weeks to reach the downstream end of the floodplain. This was slightly faster than a previous estimate of flood attenuation, estimating 4-6 weeks between Lukulu and Senanga (Beilfuss 2012). The long travel times corresponded well with 
investigations on the seasonal variation in flooded area, as previously shown for the Kafue Flats (Meier et al. 2010), and with estimations of the river discharge spending time on the floodplain (Zurbrügg et al. 2012). Compared to these approaches, using the water level records to calculate the residence time of water on the floodplain has the advantage that (1) water level records are much more easily obtained than the size of flooded areas, (2) recording is not affected by cloud cover, which often limits satellite approaches, and (3) it is not sensitive to spatial sampling variability along the floodplain. In previous efforts to define the interaction between river and floodplain in the Zambezi catchment, bankfull capacity along the river was used to determine locations of floodplain filling and draining (Zuijdgeest et al. 2015; Zurbrügg et al. 2012). As it is generally not feasible to determine bankfull capacity continuously, the precision of the locations is clearly impacted by the spatial sampling resolution. As the travel-time approach results in an integrated view of the river-floodplain interactions, this is not dependent on spatial sampling resolution.

Spatially explicit hydrological modeling of floodplain processes remains a challenge, but for the Zambezi catchment distinct progress has been made, e.g. Cohen Liechti et al. (2014). As a future step, these authors suggested to include equations for water quality parameters. Quantification of the correlations between travel time of the water over the floodplain and the observed concentrations in the main channel at Senanga could provide such equations. To this end, the data were fitted with trend lines that describe how respective concentration is impacted by prolonged residence time on the floodplain during rising and falling water levels (Table 1). During rising water levels, the oxygen concentrations were exponentially linked to the travel time, whereas $\mathrm{CO}_{2}$ and DOC were both well described by the natural logarithm of the travel time. During falling water levels, oxygen was dependent on the natural logarithm, while the increase in $\mathrm{CO}_{2}$ with increasing travel time was best described by an exponential function. No statistical trends could be discerned for DOC during falling water levels, and SPM concentrations throughout the year. The time since the onset of the flood was more crucial in determining the SPM concentrations in the river. These different dynamics of particulate and dissolved phases should be noted, and in future carbon and nutrient budgets, this clear difference needs to be considered. At present, these equations are locationspecific to the Barotse Plains, but their more general applicability should be tested via analysis of other tropical floodplain systems.

\section{Greenhouse gas emissions from floodplains}

Wetlands and floodplains are often considered and described as hotspots or biogeochemical reactors, with large potential of greenhouse gas emissions (Raymond et al. 2013). Varying patterns of organic matter respiration and consequent fluxes of $\mathrm{CO}_{2}$ and methane have been reported for various (sub-) tropical floodplains. These variations have not yet been linked to a governing mechanism. In rivers, hydrological storage and increased residence times have been identified as factors increasing aquatic respiration (Battin et al. 2008).

In the Barotse Plains, the lack of correlation between $\mathrm{O}_{2}$ concentration and NPP and respiration strongly suggested that the changes in oxygen concentration in the river were not caused by in-stream respiration processes, but were dominated by the mixing with oxygen-depleted floodplain water. This has previously been shown to cause in-stream oxygen conditions to drop along the Kafue Flats (Zurbrügg et al. 2012). During rising water levels, oxygen concentrations decreased and carbon dioxide concentrations increased simultaneously as a function of the travel time over the floodplain (Fig. 9). During receding water levels, longer travel times still led to lower oxygen concentrations and raised $\mathrm{pCO}_{2}$, though they were not of the magnitude as observed during rising water levels. A negative correlation between oxygen and carbon dioxide concentrations has previously been reported for the Zambezi, with lowest oxygen values observed downstream of floodplain systems (Teodoru et al. 2015).

Considering these observations, we suggest that travel time of the flood pulse could be a determining factor for the extent of organic matter degradation in river-floodplain systems. We hypothesize that at short travel times, organic matter is simply transferred from the floodplain to the river to be degraded further downstream, whereas at longer travel times the degradation processes are occurring on the floodplain. As such, riverine $\mathrm{CO}_{2}$ emissions would also shift from the floodplain system to downstream ecosystems as travel times get shorter. 
Table 1 Fitted trend lines for $\mathrm{O}_{2}, \mathrm{CO}_{2}$, DOC, and SPM concentrations as a function of travel time (TT) during rising and falling water levels

\begin{tabular}{lllll}
\hline & $\begin{array}{l}\text { Water } \\
\text { levels }\end{array}$ & Formula & $\begin{array}{l}\text { Residual standard } \\
\text { error }\end{array}$ & $\begin{array}{l}\text { Achieved convergence } \\
\text { tolerance }\end{array}$ \\
\hline $\mathrm{O}_{2}\left(\mathrm{mg} \mathrm{L}^{-1}\right)$ & Rising & $\mathrm{O}_{2}=-9.62+22.0 \times \mathrm{TT}^{-0.173}$ & 0.389 & $5.82 \mathrm{e}-07$ \\
& Falling & $\mathrm{O}_{2}=4.37+0.43 \times \ln (34-\mathrm{TT})$ & 0.454 & $6.36 \mathrm{e}-08$ \\
$\mathrm{CO}_{2}(\mathrm{ppm})$ & Rising & $\mathrm{CO}_{2}=-6.37 \mathrm{e} 4+5.84 \mathrm{e} 3 \times \ln$ & 823 & $7.76 \mathrm{e}-08$ \\
& & $(1.00 \mathrm{e} 4 \times \mathrm{TT}-5.30)$ & $9.71 \mathrm{e}-06$ \\
& Falling & $\mathrm{CO}_{2}=2.17 \mathrm{e} 3+4.49 \mathrm{e}-2 \times \mathrm{TT}^{3.13}$ & 642 & $3.49 \mathrm{e}-09$ \\
$\mathrm{DOC}(\mu \mathrm{M})$ & Rising & DOC $=204+127 \times \ln (\mathrm{TT}-5.3)$ & 70.5 & \\
$\mathrm{SPM}(\mathrm{mg}$ & Falling & No significant correlation & & \\
$\left.\mathrm{L}^{-1}\right)$ & Rising & No significant correlation & & \\
\hline
\end{tabular}

The residual standard error gives the average error of calculating the concentration based on the travel time. For example, for $\mathrm{O}_{2}$ during rising water levels: on average, using the regression line to predict the concentration from the travel time, this results in an error of $0.39 \mathrm{mg} \mathrm{L}^{-1}$

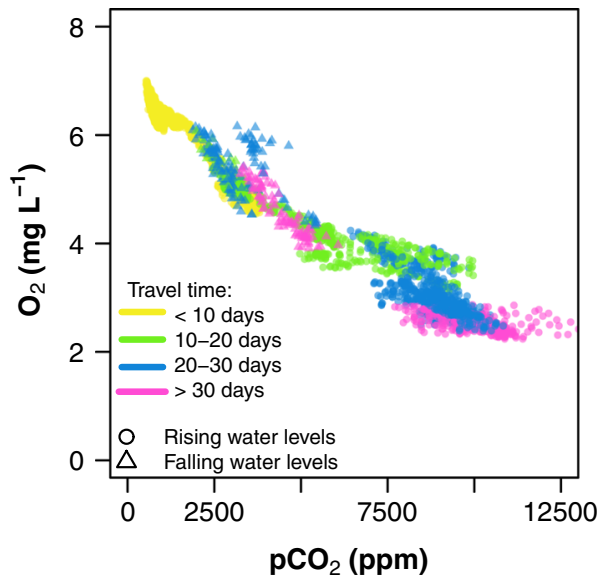

Fig. 9 Relationship between oxygen and carbon dioxide concentrations in the river at Senanga, as a function of travel time over the floodplain. Data missing between March 11 and April 12 due to instrument malfunction

To test this hypothesis for other systems, seasonal information on both hydrology and biogeochemistry is needed, which is somewhat scarce for (sub-) tropical floodplains and wetlands. In floodplains and marshes in the Murray-Darling Basin (Australia), respiration rates were found to be higher than the rates measured in the river channel (Kobayashi et al. 2013). This is in contrast to Amazonian floodplains, where Richey et al. (2002) proposed that in-stream respiration of terrestrially-derived organic matter was driving $\mathrm{CO}_{2}$ evasion rates. A more detailed analysis of travel times could possibly reconcile such divergent observations.
The floodplain and swamp areas in the MurrayDarling basin have limited connectivity to the main channel, so there would be very little delivery of organic matter to the main channel. At these very long travel times, emissions of greenhouse gases linked to organic matter degradation originate from the floodplain. At the downstream end of Richey et al. (2002) study area in the Amazon catchment, simulated water levels were estimated to be ahead of the observed water levels by 15-25 days (Paiva et al. 2013). This discrepancy was caused by the flood retention by the floodplain.

These studies suggested different locations where organic-matter degradation occurred, and we suggest that this can be explained by the varying travel times over these three floodplain systems. In the Amazon, at shorter travel times, degradation was assumed to occur in the main channel, whereas in the Murray-Darling, at very long travel times, degradation of organic matter and emissions of $\mathrm{CO}_{2}$ occurred on the floodplain. So in general, during times of short and intermediate travel times (roughly up to three weeks), a larger fraction of terrestrially-derived organic matter would be degraded in the main channel of a tropical river, as was found in the Amazon catchment and at shorter travel times in the Zambezi. This means that emissions from floodplains are smaller at such times, but that downstream systems could have uncharacteristically high emission rates due to floodplain inputs of labile organic matter at shorter travel times. At longer travel 
times, degradation occurs on the floodplain, and high emissions of greenhouse gasses can be found there, as in the Murray-Darling study.

This preliminary comparison shows that a more detailed analysis based on travel times could potentially reconcile apparently conflicting spatial patterns in different floodplain systems and therefore contribute to a general understand of tropical floodplain dynamics. This concept provides a governing mechanism for the trend of increasing riverine $\mathrm{pCO}_{2}$ values with increasing wetland coverage in tropical catchments (Borges et al. 2015). Recent work showed how the retention time of water in freshwater ecosystems is driving the remineralization rates of organic matter, and suggested a strong connection between catchment hydrology and carbon processes in inland waters (Catalan et al. 2016). Our results further highlight this connection between flood cycles and river-floodplain greenhouse gas emissions.

\section{Conclusions}

Our data highlights the need for time series, rather than snap shots to improve our understanding of highly dynamic river-floodplain systems. We showed that the calibrated data of DOC, SPM, and $\mathrm{CO}_{2}$ concentrations from high-resolution sensor data can be obtained for full flooding cycles in remote areas, and that such approaches provide opportunities to reveal patterns and processes.

Oxygen, DOC, $\mathrm{CO}_{2}$, and SPM concentrations in the river exhibit hysteresis behavior in relation to discharge and travel time of the water over the floodplain. There are distinctly different regimes during rising and falling water levels, with potentially different sources of organic matter. We propose three phases to describe these different regimes, from expansion to maximum to contraction. Relationships between travel time of the flood pulse and oxygen and carbon dioxide concentrations highlight how hydrological conditions drive the biogeochemistry in tropical river-floodplain systems. This interaction between hydrology and biogeochemistry implies that floodplains become more intense hotspots for greenhouse gases at longer travel times of the flood pulse.

Acknowledgments The authors thank Christian Dinkel and Kristina Peterson for fieldwork assistance. A big thank you to
Gerard and Graham from Barotse Tiger Camp and to Mr. Charles from Senanga Safaris for hosting the probes. Discussions with Christian Teodoru were very much appreciated, and comments from Marie-Sophie Maier, our editor Chris Evans, and two anonymous reviewers helped improve the manuscript. Prof. Imasiku Nyambe (University of Zambia and its Integrated Water Resource Management Center), the Zambia Wildlife Authority, and the Zambezi River Authority (specifically Mr. Sakala) provided institutional support. Funding for this study came from the Competence Center for Environment and Sustainability (CCES) of the ETH domain, the Swiss National Science Foundation (Grants No. 128707 and 157750) and Eawag.

Author contributions A.L.Z. and B.W. were responsible for study design. A.L.Z. and S.B. performed the fieldwork and laboratory analyses. Data interpretation was performed by A.L.Z. with S.B. and supported by B.W. The manuscript was prepared by A.L.Z. with contributions from both co-authors.

\section{Compliance with ethical standards}

Conflict of Interest The authors declare that they have no conflict of interest.

Open Access This article is distributed under the terms of the Creative Commons Attribution 4.0 International License (http:// creativecommons.org/licenses/by/4.0/), which permits unrestricted use, distribution, and reproduction in any medium, provided you give appropriate credit to the original author(s) and the source, provide a link to the Creative Commons license, and indicate if changes were made.

\section{References}

Andreae MO (1991) Biomass burning - its history, use, and distribution and its impact on environmental quality and global climate. In: Global biomass burning: atmospheric, climatic, and biospheric implications, MIT Press, Cambridge

Bass AM, O'Grady D, Leblanc M, Tweed S, Nelson PN, Bird MI (2014) Carbon dioxide and methane emissions from a wet-dry tropical floodplain in northern Australia. Wetlands 34:619-627. doi:10.1007/s13157-014-0522-5

Battin TJ et al (2008) Biophysical controls on organic carbon fluxes in fluvial networks. Nat Geosci 1:95-100. doi:10. 1038/ngeo101

Battin TJ, Luyssaert S, Kaplan LA, Aufdenkampe AK, Richter A, Tranvik LJ (2009) The boundless carbon cycle. Nat Geosci 2:598-600. doi:10.1038/ngeo618

Beilfuss R (2012) A risky climate for Southern African hydro: assessing hydrological risks and consequences for Zambezi River Basin dams. Technical report, International rivers, Berkeley

Belger L, Forsberg BR, Melack JM (2011) Carbon dioxide and methane emissions from interfluvial wetlands in the upper 
Negro River basin, Brazil. Biogeochemistry 105:171-183. doi:10.1007/s10533-010-9536-0

Borges AV et al (2015) Divergent biophysical controls of aquatic $\mathrm{CO}_{2}$ and $\mathrm{CH}_{4}$ in the World's two largest rivers. Sci Rep 5:15614. doi:10.1038/srep15614

Catalan N, Marce R, Kothawala DN, Tranvik LJ (2016) Organic carbon decomposition rates controlled by water retention time across inland waters. Nat Geosci 9:501-504. doi:10. 1038/ngeo 2720

Chaparro G, Fontanarrosa MS, Schiaffino MR, de Tezanos Pinto P, O'Farrell I (2014) Seasonal-dependence in the responses of biological communities to flood pulses in warm temperate floodplain lakes: implications for the "alternative stable states" model. Aquat Sci 76:579-594. doi:10.1007/ s00027-014-0356-5

Cohen Liechti T, Matos JP, Ferràs Segura D, Boillat J-L, Schleiss AJ (2014) Hydrological modelling of the Zambezi River Basin taking into account floodplain behaviour by a modified reservoir approach. Int $\mathrm{J}$ River Basin Manag 12:29-41. doi:10.1080/15715124.2014.880707

DelSontro T, Kunz MJ, Kempter T, Wüest A, Wehrli B, Senn DB (2011) Spatial heterogeneity of methane ebullition in a large tropical reservoir. Environ Sci Technol 45:9866-9873. doi:10.1021/es2005545

Downing JA et al (2006) The global abundance and size distribution of lakes, ponds, and impoundments. Limnol Oceanogr 51:2388-2397. doi:10.4319/lo.2006.51.5.2388

Euroconsult Mott MacDonald (2007) Rapid assessment-final report. SADC-WD/Zambezi River authority, SIDA, DANIDA, Norwegian Embassy Lusaka

Gallardo B, Español C, Comin FA (2012) Aquatic metabolism short-term response to the flood pulse in a Mediterranean floodplain. Hydrobiologia 693:251-264. doi:10.1007/ s10750-012-1126-9

Giorgino T (2009) Computing and visualizing dynamic time warping alignments in R: the dtw Package. J Stat Softw $31: 1-24$

Hamilton SK, Sippel SJ, Melack JM (1995) Oxygen depletion and carbon dioxide and methane production in waters of the Pantanal wetland of Brazil. Biogeochemistry 30:115-141. doi:10.1007/BF00002727

Hughes RH, Hughes JS (1992) A directory of African wetlands. UNEP/IUCN/WCMC, Nairobi/Gland/Cambridge

Junk WJ, Bayley PB, Sparks RE (1989) The flood pulse concept in river-floodplain systems. In: Dodge DP (ed) Proceedings of the international large river symposium. Canadian special publication of fisheries and aquatic sciences 106, pp 110-127

Kaller MD, Keim RF, Edwards BL, Raynie Harlan A, Pasco TE, Kelso WE, Rutherford AD (2015) Aquatic vegetation mediates the relationship between hydrologic connectivity and water quality in a managed floodplain. Hydrobiologia 760:29-41. doi:10.1007/s10750-015-2300-7

Kney AD, Brandes D (2007) A graphical screening method for assessing stream water quality using specific conductivity and alkalinity data. J Environ Manag 82:519-528. doi:10. 1016/j.jenvman.2006.01.014

Kobayashi $\mathrm{T}$ et al (2011) Longitudinal spatial variation in ecological conditions in an in-channel floodplain river system during flow pulses. River Res Appl 27:461-472. doi:10.1002/rra.1381
Kobayashi T, Ralph T, Ryder D, Hunter S (2013) Gross primary productivity of phytoplankton and planktonic respiration in inland floodplain wetlands of Southeast Australia: habitatdependent patterns and regulating processes. Ecol Res 28:833-843. doi:10.1007/s11284-013-1065-6

Kunz MJ, Anselmetti FS, Wüest A, Wehrli B, Vollenweider A, Thüring S, Senn DB (2011a) Sediment accumulation and carbon, nitrogen, and phosphorus deposition in the large tropical reservoir Lake Kariba (Zambia/Zimbabwe). J Geophys Res 116:G03003. doi:10.1029/2010jg001538

Kunz MJ, Wüest A, Wehrli B, Landert J, Senn DB (2011b) Impact of a large tropical reservoir on riverine transport of sediment, carbon, and nutrients to downstream wetlands. Water Resour Res 47:W12531. doi:10.1029/ $2011 w r 010996$

Lambert T, Teodoru CR, Nyoni FC, Bouillon S, Darchambeau F, Massicotte P, Borges AV (2016) Along-stream transport and transformation of dissolved organic matter in a large tropical river. Biogeosciences 13:2727-2741. doi:10.5194/ bg-13-2727-2016

Marcarelli AM, Kirk RWV, Baxter CV (2010) Predicting effects of hydrologic alteration and climate change on ecosystem metabolism in a western U.S. river. Ecol Appl 20:2081-2088. doi:10.1890/09-2364.1

Meier P, Wang H, Milzow C, Kinzelbach W (2010) Remote sensing for hydrological modeling of seasonal wetlands concepts and applications. In: ESA living planet symposium, European Space Agency, Bergen, 28 June-2 July 2010

Melack JM (2011) Riverine carbon dioxide release. Nat Geosci 4:821-822. doi:10.1038/ngeo1333

Millero FJ (1979) The thermodynamics of the carbonate system in seawater. Geochim Cosmochim Ac 43:1651-1661. doi:10.1016/0016-7037(79)90184-4

Mitsch WJ, Gosselink JG (2007) Wetlands, 4th edn. Wiley, Hoboken

Mitsch W, Nahlik A, Wolski P, Bernal B, Zhang L, Ramberg L (2010) Tropical wetlands: seasonal hydrologic pulsing, carbon sequestration, and methane emissions. Wetl Ecol Manag 18:573-586. doi:10.1007/s11273-009-9164-4

Mladenov N, McKnight D, Wolski P, Ramberg L (2005) Effects of annual flooding on dissolved organic carbon dynamics within a pristine wetland, the Okavango Delta, Botswana. Wetlands 25:622-638. doi:10.1672/0277-5212(2005)025

Moreira-Turcq P et al (2013) Seasonal variability in concentration, composition, age, and fluxes of particulate organic carbon exchanged between the floodplain and Amazon River. Global Biogeochem Cy 27:119-130. doi:10.1002/ gbc. 20022

Mori A, Uchida S, Kurazume R, Taniguchi RI, Hasegawa T, Sakoe H (2006) Early recognition and prediction of gestures. In: Pattern recognition. 18th international conference on pattern recognition 2006. pp 560-563. doi:10.1109/ ICPR.2006.467

O'Connell M, Baldwin DS, Robertson AI, Rees G (2000) Release and bioavailability of dissolved organic matter from floodplain litter: influence of origin and oxygen levels. Freshwater Biol 45:333-342. doi:10.1111/j.13652427.2000.00627.x

Oeurng C, Sauvage S, Coynel A, Maneux E, Etcheber H, Sánchez-Pérez JM (2011) Fluvial transport of suspended 
sediment and organic carbon during flood events in a large agricultural catchment in southwest France. Hydrol Process 25:2365-2378. doi:10.1002/hyp.7999

Paiva RCD, Buarque DC, Collischonn W, Bonnet M-P, Frappart F, Calmant S, Bulhões Mendes CA (2013) Large-scale hydrologic and hydrodynamic modeling of the Amazon River basin. Water Resour Res 49:1226-1243. doi:10. 1002/wrcr.20067

Pierrot D, Lewis E, Wallace DWR (2006) MS Excel program developed for $\mathrm{CO}_{2}$ system calculations. Carbon dioxide Information Analysis Center, Oak Ridge National Laboratory, US Department of Energy, Oak Ridge. doi:10.3334/ CDIAC/otg

Raymond PA et al (2013) Global carbon dioxide emissions from inland waters. Nature 503:355-359. doi:10.1038/ nature 1276

Richey JE, Melack JM, Aufdenkampe AK, Ballester VM, Hess LL (2002) Outgassing from Amazonian rivers and wetlands as a large tropical source of atmospheric $\mathrm{CO}_{2}$. Nature 416:617-620. doi:10.1038/416617a

Roach KA, Winemiller KO, Davis SE (2014) Autochthonous production in shallow littoral zones of five floodplain rivers: effects of flow, turbidity and nutrients. Freshwater Biol 59:1278-1293. doi:10.1111/fwb.12347

Robertson AI, Bunn SE, Walker KF, Boon PI (1999) Sources, sinks and transformations of organic carbon in Australian floodplain rivers. Mar Freshwater Res 50:813-829. doi:10. 1071/MF99112

Rovira A, Batalla RJ (2006) Temporal distribution of suspended sediment transport in a Mediterranean basin: the Lower Tordera (NE Spain). Geomorphology 79:58-71. doi:10. 1016/j.geomorph.2005.09.016

Staehr PA et al (2010) Lake metabolism and the diel oxygen technique: state of the science. Limnol Oceanogr-Meth 8:628-644. doi:10.4319/lom.2010.8.0628
Stewart JA (2001) A simple stream monitoring technique based on measurements of semiconservative properties of water. Environ Manag 27:37-46. doi:10.1007/s002670010132

Teodoru CR, Nyoni FC, Borges AV, Darchambeau F, Nyambe I, Bouillon S (2015) Dynamics of greenhouse gases $\left(\mathrm{CO}_{2}\right.$, $\mathrm{CH}_{4}, \mathrm{~N}_{2} \mathrm{O}$ ) along the Zambezi River and major tributaries, and their importance in the riverine carbon budget. Biogeosciences 12:2431-2453. doi:10.5194/bg-12-2431-2015

Thompson MY, Brandes D, Kney AD (2012) Using electronic conductivity and hardness data for rapid assessment of stream water quality. J Environ Manag 104:152-157. doi:10.1016/j.jenvman.2012.03.025

Wamulume J, Landert J, Zurbrügg R, Nyambe I, Wehrli B, Senn DB (2011) Exploring the hydrology and biogeochemistry of the dam-impacted Kafue River and Kafue Flats (Zambia). Phys Chem Earth 36:775-788. doi:10.1016/j.pce. 2011.07.049

Ward JV, Stanford JA (1995) The serial discontinuity concept: extending the model to floodplain rivers. Regul River 10:159-168. doi:10.1002/rrr.3450100211

Zuijdgeest AL, Zurbrügg R, Blank N, Fulcri R, Senn DB, Wehrli B (2015) Seasonal dynamics of carbon and nutrients from two contrasting tropical floodplain systems in the Zambezi River Basin. Biogeosciences 12:7535-7547. doi:10.5194/ bg-12-7535-2015

Zurbrügg R, Wamulume J, Kamanga R, Wehrli B, Senn DB (2012) River-floodplain exchange and its effects on the fluvial oxygen regime in a large tropical river system (Kafue Flats, Zambia). J Geophys Res 117:G03008. doi:10. 1029/2011jg001853

Zurbrügg R, Suter S, Lehmann MF, Wehrli B, Senn DB (2013) Organic carbon and nitrogen export from a tropical damimpacted floodplain system. Biogeosciences 10:23-38. doi:10.5194/bg-10-23-2013 